\title{
KONSERVASI LINGKUNGAN MENGGUNAKAN GERAKAN PENGHIJAUAN
}

\author{
Mohamad Bastomi*, Ahmad Naufal \\ Fakultas Ekonomi dan Bisnis, Universitas Islam Malang \\ Korespondensi email: mb.tomi@unisma.ac.id
}

\begin{abstract}
ABSTRAK
Kondisi lingkungan alami yang setiap tahunnya semakin memprihatinkan. Manusia semakin tidak peduli, sehingga kerusakan lingkungan alam pun tidak dapat dihindari. Banyaknya kerusakan lingkungan akibat dari ulah manusia sendiri diantaranya pembalakan hutan secara liar yang mengakibatkan tanah longsor, pembuangan sampah yang dapat menyumbat saluran air sehingga banjir, kualitas tanah yang menurun karena tercemar oleh bahan-bahan plastik, limbah dan masih banyak lainnya. Kepedulian terhadap lingkungan harus ditanamkan sejak dini agar kesadaran akan menjaga lingkungan sekitar tertanam, sehingga kerusakan lingkungan dapat terkurangi. Kegiatan penghijauan yang dilakukan yaitu berupa menanam pohon sukun diarea persawahan yang masih minim pepohonan di Dusun Prijek Lor Kab. Lamongan. Selain dapat menaggulangi permasalahan alam seperti akarnya dapat menahan air yang terlalu deras, rimbunnya daun pohon sukun juga dapat meneduhkan area tersebut melihat tidak terdapatnya pohon sepanjang jalan tersebut. Daun sukun sendiri dapat dimanfaatkan sebagai obat alami untuk kesehatan seperti menurunkan tekanan darah, mengurangi peradangan, melindungi kesehatan jantung dan mencegah pertumbuhan sel kanker. Dan kayunyapun bisa di manfaatkan untuk pembuatan perabotan rumah tangga sebagai contoh kursi, meja dan lain sebagainya.
\end{abstract}

Kata Kunci: konservasi lingkungan; gerakan penghijauan; perlindungan alam.

\section{PENDAHULUAN}

Lingkungan merupakan ekosistem bagi mahluk hidup tanpa terkecuali manusia, yang sudah barang tentu memiliki pengaruh besar jika terdapat kerusakan di salah satunya (Yunik'ati et al., 2019). Kondisi lingkungan yang ada setiap tahunnya mengalami penurunan Permasalahan tentang lingkungan menjadi ancaman yang tiada hentinya. Kerusakan lingkungan sebagian besar disebabkan oleh perilaku manusia (Nugroho et al., 2020; Restuningdiah et al., 2021). Banyak kerusakan lingkungan yang terjadi di Indonesia diantaranya pembalakan liar dan penggunaan sumber daya alam yang secara berlebihan, tanpa ada konservasi yang berkelanjutan (Reflita, 2015; Listiyani, 2017). Banyak kerusakan lingkungan yang diakibatkan dari sampah. Sampah yang tidak di olah secara baik akan berdampak pada tercemarnya lingkungan, terganggunya kehidupan mahluk lain serta dapat menimbulkan bencana alam salah satunya bencana banjir (Santosa, 2013). Berdasarkan permasalahan tersebut, menumbuhkan kesadaran dan kepedulian masyarakat terhadap lingkungan sekitar sangat penting. Peduli lingkungan merupakan sikap dan tindakan yang selalu diupayakan untuk mencegah kerusakan lingkungan sekitarnya dan menumbuhkan upaya-upaya untuk memperbaiki kerusakan alam yang sudah terjadi (Clourisa et al., 2021).

Sikap peduli lingkungan hendaknya ditanamkan sejak dini sebagai generasi masa depan yang menjadi agen perubahan (Tabi'in, 2017; Zakaria, 2017). Penanaman sikap peduli 
lingkungan di Dusun Prijek Lor Kab. Lamongan. Kegiatan yang dapat dilakukan dalam menumbuhkan kepedulian siswa terhadap lingkungan, yaitu melalui kegiatan penghijauan dan pengelolaan sampah. Penghijauan adalah segala upaya untuk memulihkan, memelihara dan meningkatkan kondisi lahan agar dapat berproduksi dan berfungsi secara optimal, baik pengatur tata air atau pelindung lingkungan. Penghijauan menjadi salah satu kegiatan yang dapat menangani kerusakan lingkungan. Jadi penghijauan adalah kegiatan penanaman pada lahan kosong di luar kawasan hutan serta pembuatan bangunan pencegah erosi tanah dengan tujuan agar lahan tersebut dapat dipulihkan dipertahankan dan ditingkatkan kembali kesuburannya.

Dengan itu, Mahasiswa KSM TEMATIK UNISMA yang melaksanakan pengabdian di Dsn Prijek Lor, Laren, Lamongan berinisiatif untuk menanam pohon di area persawahan yang telah kami survei, terdapat lahan yang belum dimanfaatkan dengan baik juga daerah tersebut masih minim pohon. Ditamabah daerah tersebut adalah daerah pingiran hilir sungai Bengawan Solo yang mana air mudah saja melewati daerah tersebut. Tanaman pohon yang kami pilih yaitu pohon sukun karena melihat dari potensi hasil buahnya, pemanfaatan daun dan kayu dan juga kerindangan dedauanan pohon sukun yang dapat meneduhkan para petani-petani sekitar. Penanaman yang kami lakukan di sepanajang jalan menuju perswahan Dsn. Prijek Lor ini merupakan jalan yang terdapat sungai kecil, sehinga akar dari pohon sukun akan mampu menahan derasnya air saat musim penghujan.

\section{METODE}

Kegiatan KSM-Tematik yang berlokasi di Desa Taman prijek Kecamatan Laren Kabupaten Lamongan dilaksanakan pada tanggal 1 Februari 2021 sampai dengan 2 Maret 2021. Kegiatan dilakukan dengan bimbingan dan arahan Dosen Pendamping Lapangan dan Mahasiswa secara individu. Kegiatan dimulai dengan melakukan survei lapangan dan diskusi bersama pihak desa terkait.

Kegiatan KSM-Tematik ini menggunakan metode community development. Community Development atau pembangunan masyarakat merupakan aktivitas yang dilakukan oleh masyarakat dengan menjadikan masyarakat sebagai subyek dan obyek dalam kegiatan dimana masyarakat mampu mengidentifikasi kebutuhan dan masalah sebagai upaya meningkatkan pembangunan masyarakat, Raharjo (Graha, 2009). Metode yang dilakukan berupa sosialisasi kepada masyarakat terkait pentingnya kelestarian alam, dilanjutkan dengan pendampingan kegiatan penanaman pohon sukun dan jati yang dilakukan dengan para petani di dusun guna untuk antisipasi tanah longsor dan banjir di musim hujan

\section{HASIL DAN PEMBAHASAN}

KSM TEMATIK UNISMA merupakan program kurikuler wajib bagi seluruh mahasiswa (S1). KSM tematik merupakan salah satu program kegiatan yang memberikan pengalaman belajar kepada mahasiswa di tengah-tengah kehidupan bermasyarakat di luar kampus. Kegiatan KSM Tematik memiliki tujuan untuk membantu masyarakat, terutama masyarakat daerah tertinggal dan juga menyelesaikan permasalahan yang dihadapi. program ini juga sebagai wadah bagi mahasiswa untuk mengaplikasikan teori-teori yang telah diperoleh di perguruan tinggi dalam sebuah wujud nyata berupa pengabdian kepada masyarakat. KSM Tematik ini dalam melaksanakan kegiatan dengan menerjunkan mahasiswa ke berbagai daerah. Salah satu lokasi yang menjadi tempat berlangsungnya KSM Tematik, yaitu di Dsn Prijek Lor Desa Tamanprijek Kecamatan Laren Kabupaten Lamongan. Kegiatan-kegiatan berupa program kerja telah disusun oleh mahasiswa untuk mengembangkan beberapa potensi yang ada di Dsn Prijek Lor. 
Sebelum pelaksanaan KSM Tematik beserta program kerja yang akan diselenggarakan sebagai bentuk pengabdian, para mahasiswa melakukan observasi untuk mengetahui permasalahan-permasalahan yang ada di sekitar Dsn. Prijek Lor. Penghijauan merupakan salah satu kegiatan yang tepat dan dapat mengembangkan sikap peduli masyarakat terhadap lingkungan sekitar. Penghijauan dalam arti luas adalah segala daya untuk memulihkan, memelihara dan meningkatkan kondisi lahan agar dapat berproduksi dan berfungsi secara optimal, baik sebagai pengatur tata air atau pelindung lingkungan. Melihat beberapa area di Dusun tersebut yang masih belum termanfaatkan dengan baik, maka penanaman beberapa pohon. Hal ini sesuai dengan hasil yang menunjukkan bahwa pelaksanaan kegiatan penghijauan dapat meningkatkan kepedulian masyarakat terhadap lingkungan Pengembangan sikap peduli. salah satunya dapat dilakukan dengan penghijauan.

Penghijauan di Dsn Prijek Lor ini dilaksanakan dengan menanam pohon sukun di beberapa tempat di area persawahan di Dsn prijek Lor yang telah di tentukan yaitu tempat di mana area tersebut masih belum termanfaatkan dengan baik. Kegiatan penanaman Penghijauan sebagai bentuk kepedulian dalam bentuk kegiatan yang dapat dilakukan oleh masyarakat dalam kesehariannya yaitu dengan bercocok tanam di sekiar rumah. Kegiatan berupa penanaman pohon bersama merupakan bentuk pelaksanaan nilai akan bentu kepedulian lingkungan.

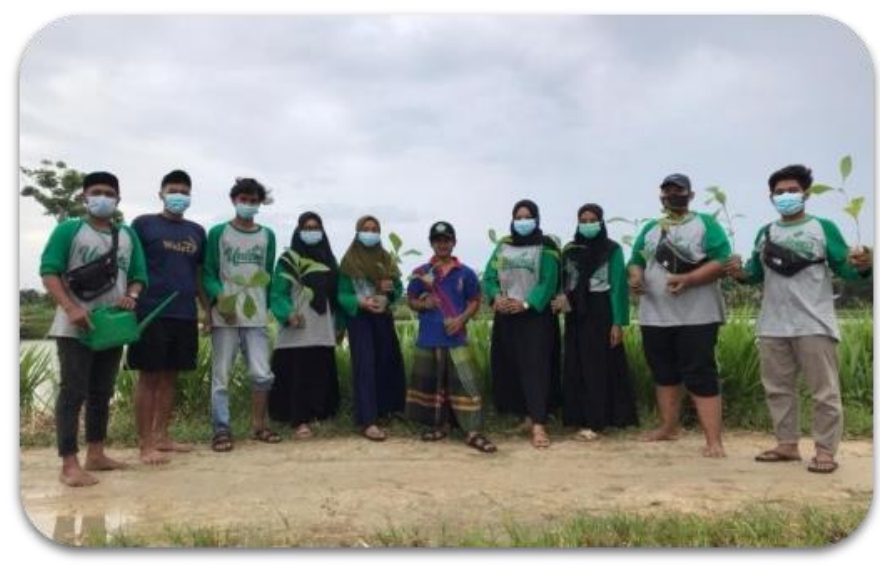

Gambar 1. Penanaman Pohon

Nilai dalam penanaman ini, diharapkan masyarakat lebih mengetahui bahwa kegiatan menanam pohon itu penting. Kegiatan penghijauan adalah salah bentuk dalam menanggulangi terjadinya bencana alam yaitu bencana banjir dan bencana tanah longsor, sehingga dengan kegiatan ini masyarakat secara tidak langsung ikut berperan dalam mitigasi bencana. Kegiatan ini dilakukan juga dimaksudkan agar masyarakat mengetahui bahwa dengan melakukan penghijau dapat memberi banyak manfaat, diantaranya yaitu memperbaiki kondisi lahan yang sudah rusak, memperbanyak persediaan oksigen dan sebagai sumber cadangan air dalam tanah. Salah satu bentuk kegiatan penghijauan yang dilakukan di Dsn Prijek Lor. Tahap selanjutnya yaitu menanam pohon sukun di daerah persawahan di Dsn Prijek Lor Kegiatan penghijauan dilakukan dengan menanam pohon sukun menunjukkan sikap masyarakat peduli lingkungan yang baik dengan mengikuti setiap kegiatan yang diarahkan oleh mahasiswa dan menunjukkan sikap antusias yang sangat tinggi.

\section{KESIMPULAN}

Setelah selesainya kegiatan KKN di Dusun Prijek Lor ini, penulis dapat menyimpulkan bahwa pelaksanaan KKN berjalan dengan lancar. Melalui program ini, dapat membentuk 
mahasiswa yang kreatif dan memiliki ide untuk mencegah kerusakan lingkungan. Selain itu, dari kegiatan KKN ini juga dapat membetuk jati diri mahasiswa dengan bertanggung jawab mengabdi pada masyarakat. Dari hasil yang telah di dapat, dapat disimpulkan bahwa penghijaun dengan penanaman pohon dapat mengatasi permasalahan lingkungan di Dusun Prijek Lor Desa Tamanprijek Kecamatan Laren Kabupaten Lamongan. Tidak hanya itu, tingkat kesadaran diri akan pentingnya melakukan penghijauan bagi lingkungan alampun meningkat Dengan adanya pohon sukun ini, diharapkan bisa berguna dan dapat bermanfaat dengan memanfaatkan hasil dari tanaman pohon sukun ini.

\section{UCAPAN TERIMA KASIH}

Ucapan terima kasih saya sampaikan kepada Seluruh masyarakat Desa Taman prijek dusun prijek lor kecamatan laren kabupaten lamongan dan sekitarnya yang senantiasa mendukung adanya program KSM-Tematik Universitas Islam Malang.

\section{DAFTAR RUJUKAN}

Clourisa, N., Susanto, A., Latief, M., \& Dyah, R. (2021). Pengenalan ecoprint guna meningkatkan keterampilan siswa dalam pemanfaatan bahan alam. Jurnal Inovasi Hasil Pengabdian Masyarakat (JIPEMAS), 4(36), 111-117. https://doi.org/10.33474/jipemas.v4i1.8974

Listiyani, N. (2017). Dampak Pertambangan Terhadap Lingkungan Hidup Di Kalimantan Selatan Dan Implikasinya Bagi Hak-Hak Warga Negara. Al-Adl, 9(1), 67-86. https://doi.org/10.31602/al-adl.v9i1.803

Nugroho, A., Fatonah, A., Wijaya, D. P. E., Putri, R. P., Fikri, M. N., Setiawan, O., Kurniawan, L. Y., Astuti, J. S., Primandika, F. T., \& Budiarti, S. A. C. (2020). Menumbuhkembangkan Kepedulian Siswa terhadap Lingkungan Melalui Kegiatan Penghijauan di MIM Pakang Andong, Boyolali. Buletin KKN Pendidikan, 2(2), 69-74. https://doi.org/10.23917/bkkndik.v2i2.11196

Reflita. (2015). Eksploitasi Alam Dan Perusakan Lingkungan (Istibath Hukum Atas Ayat-Ayat Lingkungan). Substantia, 17(2), 147-158. https://doi.org/10.22373/substantia.v17i2.4101

Restuningdiah, N., Nagari, P. M., Jati, F. D., \& Azzardina, A. (2021). Literasi bank sampah dan asuransi sampah sebagai upaya peningkatan kesejahteraan masyarakat. Jurnal Inovasi Hasil Pengabdian Masyarakat (JIPEMAS), 4(1), 144-152. https://doi.org/10.33474/jipemas.v4i1.9140

Santosa, R. W. (2013). Dampak Pencemaran Lingkungan Laut Oleh Perusahaan Pertambangan Terhadap Nelayan Tradisional. Lex Administratum, 1(2), 65-78. https://ejournal.unsrat.ac.id/index.php/administratum/article/view/3017

Tabi'in, A. (2017). Menumbuhkan Sikap Peduli Pada Anak Melalui Interaksi Kegiatan Sosial. IJTIMAIYA: Journal of Social Science Teaching, 1(1), 39-59. https://doi.org/10.21043/ji.v1i1.3100

Yunik'ati, Imam, R. M., Hariyadi, F., \& Choirotin, I. (2019). Sadar Pilah Sampah Dengan Konsep 4R (Reduce, Reuse, Recycle, Replace) Di Desa Gedongarum, Kanor, Bojonegoro. Jurnal Inovasi Hasil Pengabdian Masyarakat (JIPEMAS), 2(2), 81-87. https://doi.org/10.33474/jipemas.v2i2.1122

Zakaria, Z. (2017). Pergerakan, Strategi Visual Literacy, dan Proses Pendidikan ala Komunitas Seni Desa. Nirmana Media. 